\title{
Some Words for Witch-Watchers ${ }^{1}$
}

I read and liked Frederick Drake's article on witchcraft. It is an earnest attempt to get at the feel of the thing, something terribly hard for us given our rationalistic preconceptions. This is not my field, so I offer this suggestion informally; it's based largely on things I learned while preparing an American Quarterly article on occultism a few years ago. ${ }^{2}$ I would suggest looking at witchcraft from the point of view of the witches. Think of all the pejorative terminology about the work of the devil as the hold-over of Christian attempts to wipe out vestiges of the older (but perfectly respectable) religions which flourished in Europe from the dawn of history, through the Classical ages, through the age of Christian conversion. Remember that folk-belief and religion cannot be separated except in the modern West, and even here only imperfectly. The old religions were occult. Occult systems and beliefs survived, especially in England, both among devout Christians and among large numbers of people who had surprisingly little contact with the Church. Many simple people failed to differentiate between one kind of religious belief and another. Many sophisticated people failed to do so, too: wasn't Cotton Mather himself once editor of an almanac filled with astrological lore? Astrology survives today and is an occult system.

Now if you, as a devout practitioner of the perfectly good beliefs your family had taught you, did something religious which happened to involve those portions of occult belief which the Church had labeled diabolical, and you were caught, you might find yourself accused of witchcraft. To pick a practice which we have all encountered, suppose you spill salt at the table, and a friend urges you to throw some over your shoulder. "Why?" you ask, and he explains. "I didn't know that," you say, and toss some salt over your shoulder. Well, you have just performed a religious act which is part of a system of belief that antedates Christianity; it involves belief in an animate universe which can be influenced by occult means. If that had been one of the aspects of the system the Church had recognized as "evil" (it wasn't-devout Christians could do it with impunity), and if you had

1 See Frederick C. Drake, "Witchcraft in the American Colonies, 1647-62," American Quarterly, XX (Winter 1968), 694-725. Because American Quarterly publishes comments on articles but discourages debates which might include a rejoinder, Professor Drake was not invited to reply.

2 "In the Mystical, Moist Night-Air," American Quarterly, XIV (Summer 1962), 198 206. 
lived in the 17th century, you might find yourself in genuine peril, though neither you nor your friend had intended diabolism. Think of witches as people persecuted for what they know is right. Think of "witchcraft" as the Christian's nasty word for a religion he is persecuting. Think of "devil" as the Christian's word for a power sacred and not evil to you.

This is not to say that Puritans or other Christians understood witchcraft this way; what I am saying is that the people they persecuted did. Some, of course, were themselves confused by the Christians' terminology, and actually had a sense that their beliefs were "evil." Others were good Christians caught in a legalistic trap who died rather than lie under oath. What we have generally missed, however, is that occult beliefs were the basis of "witchcraft," and were very widespread, both among Christians and "witches." "Witches" were not simply self-deluded old ladies, but rather communicants of an ancient and impressive religious system. We should see that the witchcraft episodes in America were essentially instances of religious persecution, made especially cruel by the characteristic Christian certainty that there it but one true way, by the force of a theocratic state and by a conception of history which saw events as God's continuing revelation to man.

StUART Levine, University of Kansas

\section{THE DARKENED SKY}

John T. Frederick

Professor Frederick considers the central importance of the religious experience and attitudes of the 19th century American authors Cooper, Hawthorne, Melville, Howells, Twain, and Henry James. Focusing on the religious problems, attitudes, and experiences as treated in the published writings of each novelist, he includes pertinent biographical data, drawing upon letters, journals, and correspondence of friends.

320 pp. $\$ 10.90$

\section{University of Notre Dame Press}

Notre Dame, Indiana 46556 